\title{
Somatostatin receptor subtype 5 (SSTR5) mRNA expression is related to histopathological features of cell proliferation in insulinomas
}

\author{
Sandra Valéria de Sá1,2, Maria Lúcia Corrêa-Giannella ${ }^{1,2}$, \\ Márcio Carlos Machado ${ }^{2}$, Jean Jorge $S$ de Souza², \\ Maria Adelaide Albergaria Pereira ${ }^{2}$, Rosely Antunes Patzina ${ }^{3}$, \\ Sheila Aparecida Coelho Siqueira ${ }^{3}$, Marcel Cerqueira César Machado ${ }^{4}$ \\ and Daniel Giannella-Neto ${ }^{1,2}$
}

\footnotetext{
${ }^{1}$ Laboratory for Cellular and Molecular Endocrinology (LIM-25), University of São Paulo School of Medicine, São Paulo, Brazil

${ }^{2}$ Diabetes Unit, Division of Endocrinology, University of São Paulo School of Medicine, São Paulo, Brazil

${ }^{3}$ Division of Pathology, University of São Paulo School of Medicine, São Paulo, Brazil

${ }^{4}$ Division of Transplant and Linear Surgery (LIM-37), University of São Paulo School of Medicine, São Paulo, Brazil
}

(Requests for offprints should be addressed to D Giannella-Neto, Av. Dr Arnaldo, 455 sala. 4305, 01246-903 São Paulo SP, Brazil; Email: dag@usp.br)

\begin{abstract}
Insulinomas are rare endocrine neoplasias that constitute the most frequent islet cell tumours. Somatostatin (SST) analogs are tentatively used to inhibit insulin secretion and control tumour growth in patients with local invasion or inoperative metastasis, but variable responses have been reported. Data regarding somatostatin receptor (SSTR) subtypes expression in insulinomas are conflicting. In this study, we evaluated 16 cases of primary insulinomas (including four primary plurihormonal tumours) and two hepatic metastases. Histopathological and immunohistochemical analysis for some features associated with tumour aggressiveness and semi-quantitative RT-PCR for SSTR1-5 and real-time qPCR for SSTR5 were performed. SSTR subtypes 1, 3, and 5 were expressed in $100 \%$, SSTR2 in $89 \%$, and SSTR 4 only in $22 \%$ of the insulinomas. SSTR 5 mRNA was positively correlated with histopathological features related to tumour aggressiveness (large tumour diameter, well-differentiated endocrine tumour with uncertain behaviour and higher number of cells with nuclear atypia). SSTR5 mRNA expression in primary insulinomas was lower than in primary plurihormonal tumours $(P<0.05)$. The observed positive correlation between SSTR5 expression and tumour size suggests that the use of SST analogues more specific to SSTR5 in the treatment of insulinomas deserves attention.
\end{abstract}

Endocrine-Related Cancer (2006) 13 69-78

\section{Introduction}

Somatostatin (SST) action is mediated by five known SST receptors (SSTR) subtypes - SSTR1, SSTR2, SSTR3, SSTR4 and SSTR5, members of G-protein-coupled membrane receptors family, with negative modulation of adenyl-cyclase (Patel 1999). The different subtypes are related to distinct cellular effects: SSTR5 seems to be involved in the control of insulin and glucagon secretions; SSTR3, and to a lesser extent SSTR2, can induce apoptosis, and SSTR1 and 5 have inhibitory effects on the cell cycle, while the function of SSTR4 remains unknown (Lamberts et al. 2002).

Insulinomas are rare endocrine neoplasias that constitute the most frequent islet cell tumours, with an estimated incidence of four cases per one million people per year. Insulinomas are usually benign 
(90\% of cases), solitary $(90 \%)$, intrapancreatic $(99 \%)$ tumours (Service et al. 1991). The smaller tumours tend to be homogeneous without local invasion or distant metastasis. Insulinomas are generally composed of sheets of small round cells and mitoses are unusual. The amount of intervening stroma is extremely variable, and may appear dense and hyalinized. There is a well-organized relationship between the neoplastic cells and the numerous stromal vessels. Three histopathological patterns are observed in insulinomas: (a) a solid, diffuse pattern; (b) a ribbon-like, trabecular pattern and (c) an acinar or duct-like pattern. More than one of these architectural patterns may occur in the same neoplasm (Solcia et al. 1997).

Although the underlying mechanisms related to subtype selectivity have not been completely elucidated, SST analogues are used in the treatment of several tumours since they may inhibit hormonal secretion, induce apoptosis and affect cell proliferation. Octreotide and lantreotide are tentatively used to inhibit insulin secretion and control tumour growth in patients with local invasion or inoperative metastasis from insulinomas, but variable responses have been reported (Dogliotti et al. 2001). Several mechanisms may account for these variable responses such as receptor down-regulation, desensitization and absence of expression of SSTR subtypes with high affinity for the analogues in the tumour (de Herder et al. 2003). The relative frequency of SSTR expression in $\beta$-cells was determined to be SSTR $1(100 \%$ of $\beta$-cells $)>$ SSTR 5 $(87 \%)>$ SSTR $2 \quad(46 \%)>$ SSTR $3 \quad(28 \%)>$ SSTR 4 (17\%) (Kumar et al. 1999) while data regarding SSTR subtypes expression in insulinomas are conflicting. Reverse transcription polymerase chain reaction (RT-PCR) analysis performed in four series of insulinomas showed the following subtype frequency: SSTR $1=$ SSTR $4 \quad(100 \%)>$ SSTR $2 \quad(75 \%)>$ SSTR 3 $(50 \%)$ in 4 cases (Kubota et al. 1994); SSTR2 = SSTR4 $=$ SSTR $5 \quad(100 \%)>$ SSTR $3 \quad(80 \%)>$ SSTR 1 $(60 \%)$ in 5 cases (Jais et al. 1997); SSTR1 $(90 \%)>$ SSTR $3 \quad(84 \%)>$ SSTR $2 \quad(74 \%)>$ SSTR $4=$ SSTR5 (42\%) in 19 cases (Papotti et al. 2002); SSTR2 $=$ SSTR5 $(70 \%)>$ SSTR1 $(50 \%)>$ SSTR3 $=$ SSTR4 (15-20\%) in 20 cases (Bertherat et al. 2003). In 36 cases studied by immunohistochemistry, Kulaksiz et al. (2002) reported SSTR3 = SSTR5 $(78 \%)>\operatorname{SSTR} 2 \mathrm{~A}(58 \%)>\operatorname{SSTR} 1(31 \%)$.

In this study, we evaluated the mRNA expression of the five SSTR subtypes in insulinomas by RT-PCR and of SSTR5 by real-time quantitative PCR (qPCR) correlating the results with histopathological and immunohistochemical data.

\section{Materials and methods}

\section{Patients and tissue samples}

From 1999-2003, tumour tissues were obtained from patients diagnosed with insulinoma, based on the clinical features of Whipple's triad of symptoms with concomitant endogenous hyperinsulinemia and positive immunohistochemistry of the tumour for insulin. During laparotomy surgery, tumour fragments were collected in sterile containers and frozen in liquid nitrogen. Eighteen insulinomas from 17 patients were included in the study: two liver metastases of insulinomas and 16 primary tumours, comprising one insulinoma from a patient diagnosed with Multiple Endocrine Neoplasia Type 1 (MEN1) syndrome, one sample corresponding to the primary insulinoma of one hepatic metastasis and 14 sporadic insulinomas. Most tumours were encapsulated and the fragments for RNA extraction were carefully removed from the central portion, in order to avoid contamination with normal pancreatic tissue. This study was approved by the Ethical Committee of Hospital das Clinicas of the University of São Paulo School of Medicine and informed consent was obtained from all patients. All laparotomies were performed by the same surgeon.

\section{Histopathological and immunohistochemical analysis}

Sections were histologically analysed by hematoxylin and eosin staining. Histopathological examination was performed based on nuclear atypia (coded as mild, moderate or severe), mitotic index (number of mitosis/10 high-power fields [HPF]), presence or absence of perineural and vascular invasion. Immunohistochemical staining was performed in paraffin embedded blocks by avidin-biotin peroxidase complex (ABC) method using anti-human chromogranin A antiserum (Biogenex Laboratories, San Ramon, CA USA), synaptophysin, insulin, SST, glucagon, gastrin, tumour protein $\mathrm{p} 53$ and proliferation-related $\mathrm{Ki}-67$ antigen (Dako Cytomation Denmark A/S, Copenhagen, Denmark). The tumours were classified as: well-differentiated endocrine tumours with benign behaviour (WDET-BB), confined to the pancreas, non-angioinvasive, no perineural invasion, $<2 \mathrm{~cm}$ in diameter, $<2$ mitoses/10HPF, and $<2 \% \mathrm{Ki}-67$ positive cells; well-differentiated endocrine tumours with uncertain behaviour (WDET-UB), confined to the pancreas with one or more of the following features: $\geqslant 2 \mathrm{~cm}$ in diameter, $2-10$ mitoses $/ 10 \mathrm{HPF}$, $>2 \% \mathrm{Ki}-67$ positive cells, angioinvasion, perineural invasion; well-differentiated endocrine carcinoma 
(WDEC), in the presence of gross local invasion and/or metastases; and metastasis of endocrine carcinoma (MEC) (Komminoth et al. 2004). All samples were evaluated by a single pathologist.

\section{RNA isolation and cDNA synthesis}

After tumour pulverization with a dismembrator (B. Braun Biotech International, Melsungen, Germany) at liquid nitrogen temperature, total RNA was prepared using TRIzol reagent (Invitrogen) according to the manufacturer's recommendations. To avoid possible genomic DNA contamination, all RNA samples were treated with RNase-free DNAse (Promega). After phenol treatment and drying, RNA was dissolved in RNase-free water and RNA concentration was spectrophotometrically determined. RNA quality was checked by agarose gel electrophoresis.

\section{Semi-quantitative RT-PCR}

mRNA expressions of SSTR subtypes in this tumour series were performed by semi-quantitative RT-PCR. Total RNA $(3 \mu \mathrm{g})$ was reverse transcribed at complementary DNA (cDNA) using SuperScript II Reverse Transcriptase and random primers (Invitrogen Life Technologies) according to manufacturer's recommendations and diluted with double distilled water to a final volume of $100 \mu \mathrm{l}$. PCR experiments were carried out in $25 \mu \mathrm{l}$ final reaction volume containing $3 \mu 1$ cDNA template, $0.5 \mu \mathrm{M}$ sense and antisense of target gene primers, $0.25 \mu \mathrm{M}$ sense and antisense of housekeeping gene primers (breakpoint cluster region $[\mathrm{BCR}]$ gene), $10 \mathrm{mM}$ Tris- $\mathrm{HCl} \mathrm{pH} 9.0$, $50 \mathrm{mM} \mathrm{KCl}, 2.0 \mathrm{mM} \mathrm{MgSO}_{4}, 0.2 \mathrm{mM}$ deoxynucleotide triphosphates (dNTPs), and 1.0 U Platinum Taq High Fidelity (Invitrogen). PCR amplification for each gene studied was performed under the following cycling conditions: initial denaturation at $94^{\circ} \mathrm{C}$ for $5 \mathrm{~min}$, denaturation at $94^{\circ} \mathrm{C}$ for $30 \mathrm{~s}$, annealing at specific temperatures $\left(55^{\circ} \mathrm{C}\right.$ for SSTR2 and SSTR $4,56^{\circ} \mathrm{C}$ for SSTR 5 and $58^{\circ} \mathrm{C}$ for SSTR1 and SSTR 3) for $45 \mathrm{~s}$ and extension at $72^{\circ} \mathrm{C}$ for $1 \mathrm{~min}$, followed by a final extension step at $72^{\circ} \mathrm{C}$ for $5 \mathrm{~min}$. The number of cycles to achieve the exponential phase for PCR amplification was 35 for all SSTR subtypes co-amplified with BCR. The PCR products were electrophoresed through a $2 \%$ agarose gel containing ethidium bromide and visualized by ultraviolet light. The band intensities of two independent experiments were analysed by Molecular Analyst Software (Bio-Rad Laboratories, Hercules, CA, USA). The mean expression levels of the target genes were normalized by the mean BCR housekeeping gene expression and the ratios of each gene expression (target gene/BCR) were calculated in all samples as arbitrary units of optical density. Human SSTR genes are intronless, and only the primers for BCR amplification were so designed that PCR products comprised portions of two contiguous exons. The primers were designed with the primer3_www.cgi $\mathrm{v} 0.2$ program (Rozen \& Skaletsky 2000) as follows:

BCR GenBank (377-bp product):

Sense: $5^{\prime}$-GAGAAGAGGGCGAACAAG-3'

Antisense: 5'-CTCTGCTTAAATCCAGTGGC-3'

SSTR1 GenBank (217-bp product):

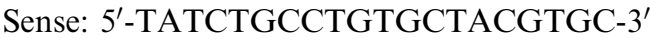

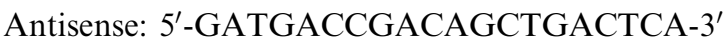

SSTR2 GenBank (281-bp product):

Sense: 5'-CAGTCATGAGCATCGACCGA-3'

Antisense: $5^{\prime}$-GCAAAGACAGATGATGGTGA- ${ }^{\prime}$

SSTR3 GenBank (188-bp product):

Sense: $5^{\prime}$-TCAGTCACCAACGTCTACATCC-3'

Antisense: $5^{\prime}$-ACGCTCATGACAGTCAGGC-3'

SSTR4 GenBank (321-bp product):

Sense: 5'-ATCTTCGCAGACACCAGACC-3'

Antisense: 5'-ATCAAGGCTGGTCACGACGA-3'

SSTR5 GenBank (222-bp product):

Sense: 5'-CGTCTTCATCATCTACACGG-3'

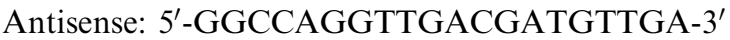

\section{SSTR5 quantitative PCR analysis}

Total RNA from 17 tumour samples were extracted using TRIzol reagent (Invitrogen) and treated with RNase-free DNAse (Promega) as described above. Transcript levels of SSTR5 was determined as the number of transcripts relative to those of housekeeping gene proteasome 26S ATPase subunit 6 (PSMC6). The primers designed with the primer3_www.cgi $\mathrm{v} 0.2$ program (Rozen \& Skaletsky 2000) were follows:

PSMC6 GenBank (196-bp product):

Sense: 5'-GCTGCGTCCAGGAAGATTAG-3' Antisense: 5'-TGCGAACATACCTGCTTCAG-3'

SSTR5 GenBank (156-bp product):

Sense: $5^{\prime}$-GTGACAACAGGACGCTGGT-3' Antisense: 5'-TGGTGACGGTCTTCATCTTG- $3^{\prime}$

qPCR analyses of SSTR5 were performed in the Rotor-Gene RG-3000 (Corbett Research, Sidney, Australia) using Quantitect SYBR Green RT-PCR for quantitative, real time, one step RT-PCR (Qiagen $\mathrm{GmbH}$, Hilden, Germany), according to the instructions provided by the manufacturer. Reactions lacking reverse transcriptase were also run to generate controls 
Table 1 Clinical and laboratory data of patients with diagnosis of insulinoma. Age and duration of symptoms were represented in median, minimum and maximum values. All other variables were represented in mean \pm S.D.

\begin{tabular}{|c|c|c|c|c|c|}
\hline & \multirow[b]{3}{*}{ All groups } & \multicolumn{4}{|c|}{ Well-differentiated endocrine tumours } \\
\hline & & \multirow{2}{*}{$\begin{array}{c}\text { Benign } \\
\text { behaviour } \\
\text { (WDET-BB) }\end{array}$} & \multirow{2}{*}{$\begin{array}{l}\text { Uncertain } \\
\text { behaviour } \\
\text { (WDET-UB) }\end{array}$} & \multicolumn{2}{|c|}{ Carcinoma } \\
\hline & & & & $\begin{array}{l}\text { Primary } \\
\text { (WDEC) }\end{array}$ & $\begin{array}{l}\text { Metastases } \\
\quad(\mathrm{MEC})\end{array}$ \\
\hline \multicolumn{6}{|l|}{ Clinical data } \\
\hline Total of patients & 17 & 9 & 6 & 1 & 2 \\
\hline Gender (M/F) & $8 / 10$ & $3 / 6$ & $3 / 3$ & $1 / 0$ & $1 / 1$ \\
\hline Age (years) & $43(14-79)$ & $30(14-71)$ & $50(22-79)$ & 43 & $60(43-77)$ \\
\hline Duration of symptoms (months) & $24(1-168)$ & $15(3-48)$ & $24(1-156)$ & 6 & $87(6-168)$ \\
\hline \multicolumn{6}{|l|}{ Laboratory data } \\
\hline Glucose (mmol/l) & $2.25 \pm 0.19$ & $1.96 \pm 0.22$ & $2.20 \pm 0.34$ & 3.28 & $3.16 \pm 0.11$ \\
\hline Insulin (pmol/l) & $302.9 \pm 69.26$ & $244.1 \pm 66.7$ & $209.7 \pm 61.2$ & 930.0 & $533.7 \pm 396.3$ \\
\hline C-peptide (nmol/l) & $1.78 \pm 0.23$ & $1.49 \pm 0.26$ & $2.28 \pm 0.50$ & 2.45 & $1.51 \pm 0.94$ \\
\hline
\end{tabular}

WDET, well-differentiated endocrine tumour; BB, benign behaviour; UB, uncertain behaviour; WDEC, well differentiated endocrine carcinoma; MEC, metastases of endocrine carcinoma

for assessment of genomic DNA contamination. Reaction mixture consisted of $12.5 \mu \mathrm{l}$ of SYBR RTPCR Master Mix, $0.25 \mu \mathrm{l}$ of QuantiTect RT Mix, $0.2 \mu \mathrm{M}$ sense/antisense primers and $5 \mu \mathrm{l}(20 \mathrm{ng} / \mu \mathrm{l})$ of total RNA template. RNA template concentrations

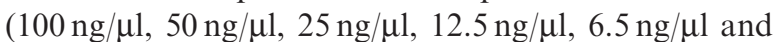
$3.2 \mathrm{ng} / \mu \mathrm{l})$ were used to generate a standard curve to evaluate the amplification efficiency of each target gene in comparison to PSMC6. The reaction was carried out under the following cycling conditions: $50^{\circ} \mathrm{C}$ for $30 \mathrm{~min}$ for reverse transcription, heated to $95^{\circ} \mathrm{C}$ for $15 \mathrm{~min}$, and then cycled 35 times at $94^{\circ} \mathrm{C}$ for 20 seconds, $60^{\circ} \mathrm{C}$ for 30 seconds and $72{ }^{\circ} \mathrm{C}$ for 30 seconds. To verify the specificity of the amplification reaction, melting-curve analysis was performed using the following parameters: $72{ }^{\circ} \mathrm{C}$ ramping to $99^{\circ} \mathrm{C}$ at $0.2{ }^{\circ} \mathrm{C} /$ second, in conjunction to an agarose gel electrophoresis to visualize the band for PSMC6 and SSTR5 with the correspondent size; $196 \mathrm{bp}$ and $156 \mathrm{bp}$, respectively. Relative quantification was calculated using the mathematical model described by Pfaffl 2001.

\section{Statistical analysis}

Nonparametric tests were employed in all comparisons. Data were classified in Van der Waerden rank scores by ranking the data, divide by one plus the number of observations transformed to a normal score by applying the inverse of the normal distribution function (Hallin \& Jurěková 1999). Spearman's $\rho$ (rho) coefficient was calculated in all correlation analysis after normalization of the data by taking the z-scores of rank of the values in increasing order subtracted by 0.5 and divided by the size of the sample ( $Q$ value). Findings were considered statistically significant at probability levels of $P<0.05$. All statistical analysis was performed using JMP Release 5.1.1 software (SAS Institute Inc, Cary, NC, USA) .

\section{Results}

The clinical and laboratory data are summarized in Table 1. The cohort observed in the present study was similar to other large series of patients (Service et al. 1991) with hypoglycaemia syndrome having a slight female predominance $(53 \%)$, median of age in the fifth decade (43 year-old), an elevated insulin level and a markedly decreased fasting glucose level. Disease duration ranged heterogeneously from 1 to 168 months, median of 24 months. The largest diameter of the tumours ranged from 6 to $55 \mathrm{~mm}$ (median $16 \mathrm{~mm}$ ). Nuclear atypia was considered as mild in 55\% $(10 / 18)$ and moderate in $45 \%(8 / 18)$ of tumour samples. Mitotic index ranged from 0 to 4 mitosis/ HPF. There was no evidence of perineural invasion and vascular in any samples. Immunoperoxidase staining for chromogranin A and synaptophysin were positive in all tumour tissues. Insulin was present with strong, moderate and weak immunostaining in $44 \%$, $28 \%$, and $22 \%$ respectively. Although metastatic tumour tissue form patient \#16 did not present immunohistochemistry for insulin, this patient had unequivocal hypoglycaemia syndrome. Three tumour tissues had weak immunoreaction for somatostatin (patients \#10, \#11 and \#15), one had strong 

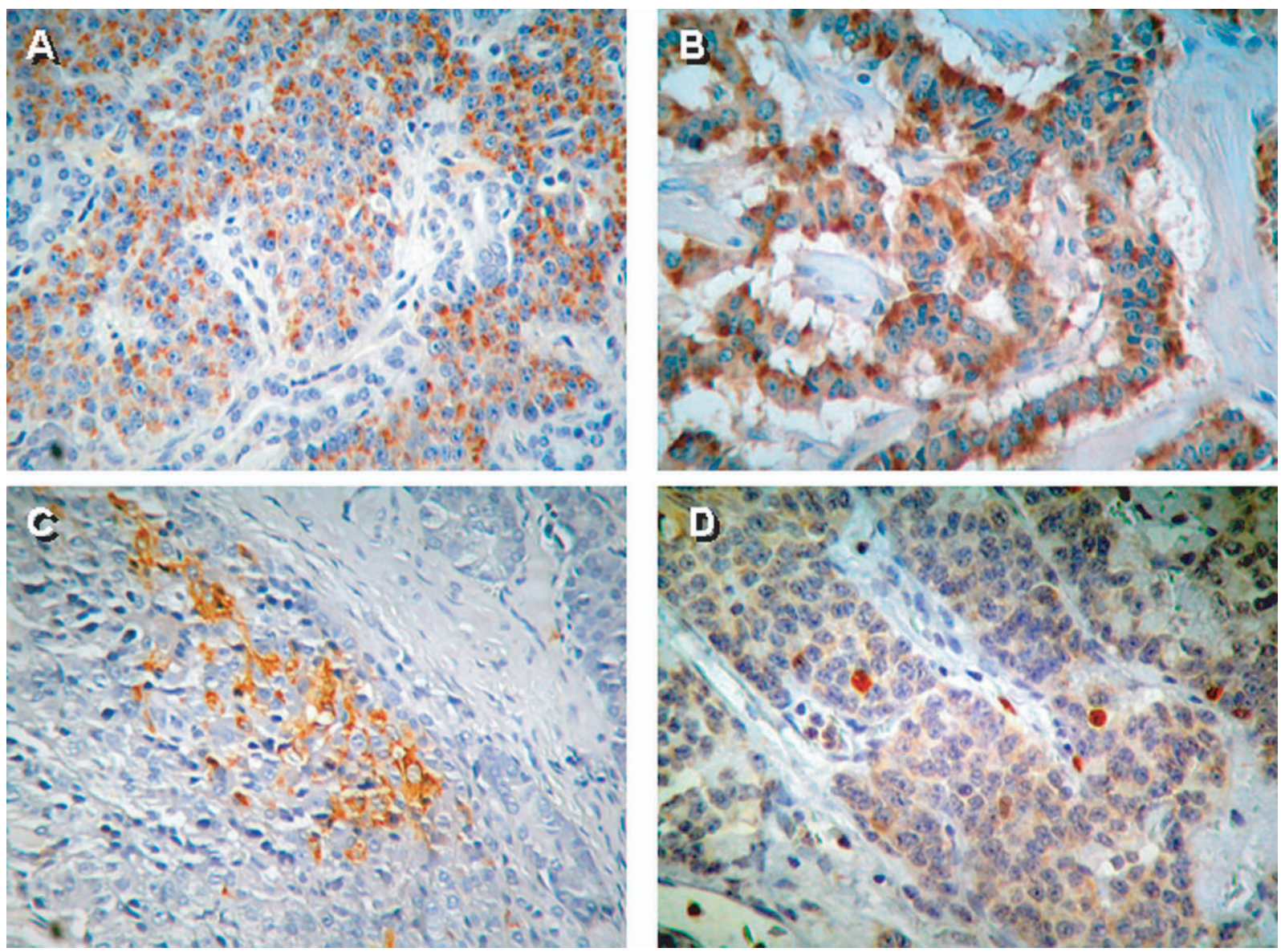

Figure 1 Representative photomicroscopic images of immunohistochemical analyses in insulinomas: (A) Immunoreactive cells for insulin showing a rather wide distribution $(\sim \times 20)$; (B) Moderate immunostaining for glucagon $(\sim \times 20)$; (C) somatostatin immunostaining shows only a few collection of cells $(\sim \times 20)$; and (D) Ki-67 proliferative index with $>2 \%$ of positive cells $(\sim \times 40)$.

immunostaining for glucagon (primary tumour from patient \#16) and none for gastrin. Positive imunoreactivity for Ki-67 in $>2 \%$ cells was demonstrated in $22 \%$ of all studied samples. Tumour protein p53 was not detected by immunohistochemistry in any tumour, including the two hepatic metastases. Figure 1 shows representative immunohistochemical images of insulin (A), glucagon (B), somatostatin (C), and Ki-67 (D). All relevant histopathological and immunohistochemical features are depicted in Table 2.

Semi-quantitative RT-PCR of SSTR subtypes mRNA revealed that SSTR subtypes 1, 3, and 5 were expressed in $100 \%$, SSTR 2 in $89 \%$, and SSTR 4 only in $22 \%$ of the insulinomas. SSTR 5 mRNA expression (by semi-quantitative RT-PCR) was significantly higher in tumours with histopathological features related to an aggressive behaviour. These findings led us to confirm the SSTR5 mRNA expression by real-time quantitative PCR (Figure 2) in all tumoural samples. SSTR5 mRNA expression levels in insulinomas from patients, classified accordingly to WHO criteria are depicted in Figure 3 which shows a statistically significant increase in SSTR5 mRNA expression (expressed as Q values) in WDET-UB [median (min-max); $0.75(0.53-0.97)]$ in comparison to WDET-BB [0.31 (0.03-0.69)], $P<0.05$. The primary carcinoma (WDEC) and the metastases presented SSTR5 mRNA levels as high as the WDET-UB.

Figure 4 depicts SSTR5 mRNA expression levels insulinoma samples classified accordingly to their size (upper panel) nuclear atypia (lower panel). SSTR5 mRNA expression was significantly higher in insulinomas larger than $15 \mathrm{~mm}(<15 \mathrm{~mm}: 0.28(0.03-0.47)$ vs $\geqslant 15 \mathrm{~mm}: 0.75(0.53-0.97)]$ and moderate nuclear atypia [mild: $0.39(0.03-0.75)$ vs. moderate: $0.81(0.25-$ 0.97)], $P<0.05)$. 
Table 2 Histopathological and immunohistochemical findings of insulinomas from the patients studied. Magnitude of immunohistochemical expressions positivity was semi-quantitatively represented by number of crosses

\begin{tabular}{|c|c|c|c|c|c|c|c|c|}
\hline \multirow[b]{2}{*}{ Patient } & \multicolumn{3}{|c|}{ Histopathological analysis } & \multicolumn{4}{|c|}{ Immunohistochemical analysis } & \multirow[b]{2}{*}{$\begin{array}{l}\text { Histological } \\
\text { classification }\end{array}$} \\
\hline & $\begin{array}{c}\text { Tumor } \\
\text { size } \\
(\mathrm{mm})\end{array}$ & $\begin{array}{l}\text { Nuclear } \\
\text { atypia }\end{array}$ & $\begin{array}{c}\text { Mitotic } \\
\text { index } \\
(/ 10 \mathrm{HPF})\end{array}$ & Insulin & Glucagon & Somatostatin & $\begin{array}{c}\text { Ki-67 } \\
\text { (\% cells) }\end{array}$ & \\
\hline 1 & 6 & Mild & 1 & +++ & - & - & $<2$ & WDET-BB \\
\hline 2 & 8 & Mild & 0 & +++ & - & - & $<2$ & WDET-BB \\
\hline 3 & 10 & Moderate & 1 & +++ & - & - & $<2$ & WDET-BB \\
\hline 4 & 17 & Mild & 0 & +++ & - & - & $<2$ & WDET-BB \\
\hline 5 & 15 & Mild & 0 & ++ & - & - & $<2$ & WDET-BB \\
\hline 6 & 10 & Mild & 0 & +++ & - & - & $<2$ & WDET-BB \\
\hline 7 & 14 & Mild & 0 & +++ & - & - & $<2$ & WDET-BB \\
\hline 8 & 13 & Mild & 0 & +++ & - & - & $<2$ & WDET-BB \\
\hline 9 & 7 & Mild & 1 & + & - & - & $<2$ & WDET-BB \\
\hline 10 & 15 & Moderate & 2 & ++ & - & + & $<2$ & WDET-UB \\
\hline 11 & 55 & Moderate & 2 & +++ & - & + & $<2$ & WDET-UB \\
\hline 12 & 20 & Moderate & 0 & ++ & - & - & $>2$ & WDET-UB \\
\hline 13 & 20 & Mild & 0 & ++ & - & - & $<2$ & WDET-UB \\
\hline 14 & 20 & Moderate & 1 & + & - & - & $<2$ & WDET-UB \\
\hline 15 & 15 & Moderate & 1 & ++ & - & + & $>2$ & WDET-UB \\
\hline \multirow{2}{*}{16} & 20 & Moderate & 1 & + & +++ & - & $>2$ & WDEC \\
\hline & 10 & Mild & 3 & - & - & - & $>2$ & MEC \\
\hline 17 & 15 & Moderate & 2 & + & - & - & $<2$ & MEC \\
\hline
\end{tabular}

HPF: high-power field; Ki-67: proliferation-related Ki-67 antigen; WDET-BB: well-differentiated endocrine tumour with benign behaviour; WDET-UB: well-differentiated endocrine tumour with uncertain behaviour; WDEC: well-differentiated endocrine carcinoma; MEC: metastasis of endocrine carcinoma.

SSTR5 mRNA expression and tumour size presented a statistically significant positive correlation $(\rho=0.71, P<0.05)$ as shown in Figure 5.

As shown in Figure 6, SSTR5 mRNA expression in primary insulinomas $\left[\begin{array}{lll}0.36 & (0.03-0.75)\end{array}\right]$ was significantly lower than in primary plurihormonal tumours $\left[\begin{array}{ll}0.83 & (0.53-0.97)] \\ \text { either WDEC-BB or }\end{array}\right.$ WDETC-UB, $P<0.05$.

Noteworthy, the arrows in figures 3-6 indicate a 64 year-old male (patient \#14) with a short history of classic Whipple's triad of hypoglycaemic symptoms for a month. Histopathological examination revealed a tumour of $20 \mathrm{~mm}$ resected from the neck of the pancreas exhibiting moderate nuclear atypia and mitotic index of $1 / 10$ HPF (Table 2). Histopathological classification referred this insulinoma as well-differentiated endocrine tumour with uncertain behaviour. A sample of this tissue was disrupted, trypsinised and cultured cells were able to grow in soft agar medium. Although this growth pattern suggests a malignant phenotype, tumour-associated antigen (Ki-67) was positive in $<2 \%$ of the cells (Table 2 ) and SSTR5 mRNA expression was low, features more compatible with a less aggressive biological behaviour. For these heterogenous characteristics, this tumour was excluded from the all analyses performed.

\section{Discussion}

Analysis of SSTR subtypes mRNA expression in a series of 18 insulinomas by semi-quantitative RT-PCR showed that SSTR subtypes 1, 3 and 5 were expressed in the totality of the studied insulinomas and SSTR subtype 2 was expressed in all but 2 tumours (89\%), while SSTR subtype 4 was expressed in only four insulinomas $(22 \%)$. SSTR distribution observed in this series does not agree entirely with the distribution previously reported which also employed RT-PCR analysis (Kubota et al. 1994, Jais et al. 1997, Papotti et al. 2002, Bertherat et al. 2003). However, frequencies of expression of SSTR subtypes 1, 5 and 4 were similar to at least one previous report. Briefly, SSTR subtype 1 and SSTR5 frequencies of $100 \%$ were reported in two small series (Kubota et al. 1994, Jais et al. 1997, respectively) and SSTR subtype 4 frequency of $20 \%$ was observed by Bertherat et al. (2003). The frequency of SSTR subtype 3 expression $(100 \%)$ observed in this series was higher than the maximum reported in other series (84\%) (Papotti et al. 2002). 


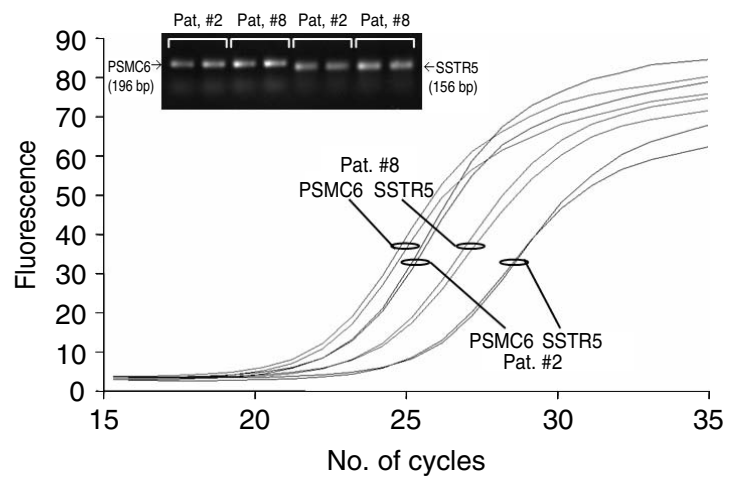

Figure 2 SSTR5 mRNA expression analysis in insulinoma samples from patients \#2 and \#8. Real-time qPCR amplification curves for comparing SSTR5 and PSMC6 mRNA expressions in duplicates. Upper panel shows electrophoresis on $3 \%$ agarose gel of amplified products of the same samples graphically depicted below.

The SSTR subtypes sequence homologies could be account for these conflicting results since different primer sets might be employed in evaluating for SSTR subtypes mRNA expression. We have managed to pick up primers set, paired to the most non-homologous regions sites as possible of SSTR isoforms, in order to circumvent any misinterpretation of the data.

An antioncogenic role has been attributed to SSTR subtype 2 in human pancreatic cancer (Delesque et al. 1997, Rochaix et al. 1999) and high levels of SSTR subtype 2 expression were positively related to a favorable prognostic in neuroblastomas (Sestini et al. 1996), breast cancers and, maybe, colorectal cancer (Buscail et al. 1996, Raggi et al. 2002). Thus, even knowing the benign nature of most insulinomas, we evaluated whether the expression of SSTR subtypes may correlate with specific histopathological data and cell proliferation markers. There was no association between lower SSTR subtype 2 mRNA expression and variables suggestive of a more aggressive biological behaviour. However, a positive relationship was observed between SSTR5 mRNA expression and histopathological features related to tumour aggressiveness, as expressed either by the criteria considered by WHO International Classification of Endocrine Tumours or by larger tumour sizes and higher number of cells with nuclear atypia. Furthermore, a positive correlation between tumour size and SSTR5 mRNA expression was also detected.

Since there is evidence supporting the involvement of SSTR5 in SST-induced anti-proliferative effects (Cordelier et al. 1997, Sharma et al. 1999), an

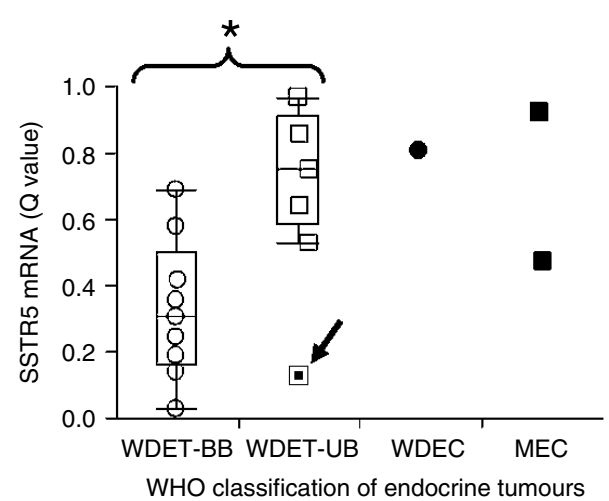

Figure 3 SSTR5 quantitative mRNA expression in insulinoma samples from patients classified accordingly to WHO International Histological Classification of Endocrine Tumours, i.e., WDET-BB, well-differentiated endocrine tumour with benign behaviour; WDET-UB, well-differentiated endocrine tumour with uncertain behaviour; WDEC, well-differentiated endocrine carcinoma; and MEC, metastasis of endocrine carcinoma. $Q$ values were calculated as described in the statistical analysis section. The ends of the box are the 25th and 75 th quantiles, respectively. The difference between the quartiles is the interquartile range. The line across the middle of the box identifies the median sample value. Each box has lines extending from the ends of the box to the outermost data point that falls within the distances computed. Arrow is indicating patient \#14 as mentioned in the text.

association between SSTR5 mRNA expression and features indicative of increased cell proliferation was unexpected. A discrepancy between SSTR5 mRNA and protein levels may not be ruled out since immunohistochemistry study was not performed. However, previous immunohistochemistry studies have shown the presence of SSTR5 receptors in insulinomas (Papotti et al. 2002, Kulaksiz et al. 2002, Patel et al. 2002) and Bertherat et al. (2003) demonstrated significant binding of a SSTR5 ligand in a series of 20 insulinomas, which argues in favour of the presence of functional SSTR5 receptors in insulinomas. Furthermore, the positive association between SSTR5 mRNA expression and at least two variables related to cell proliferation and tumour aggressiveness support a biological relevance for these findings. Considering the inhibitory effects of activated SSTR5 on the cell cycle, it is possible that SSTR5 augmented expression constitutes a cellular response to increased proliferation, a compensatory mechanism that tries to control aberrant cell proliferation.

The positive correlation between SSTR5 expression and tumour size suggests that studying the effect of SSTR5 analogues in insulinomas may be an interesting 

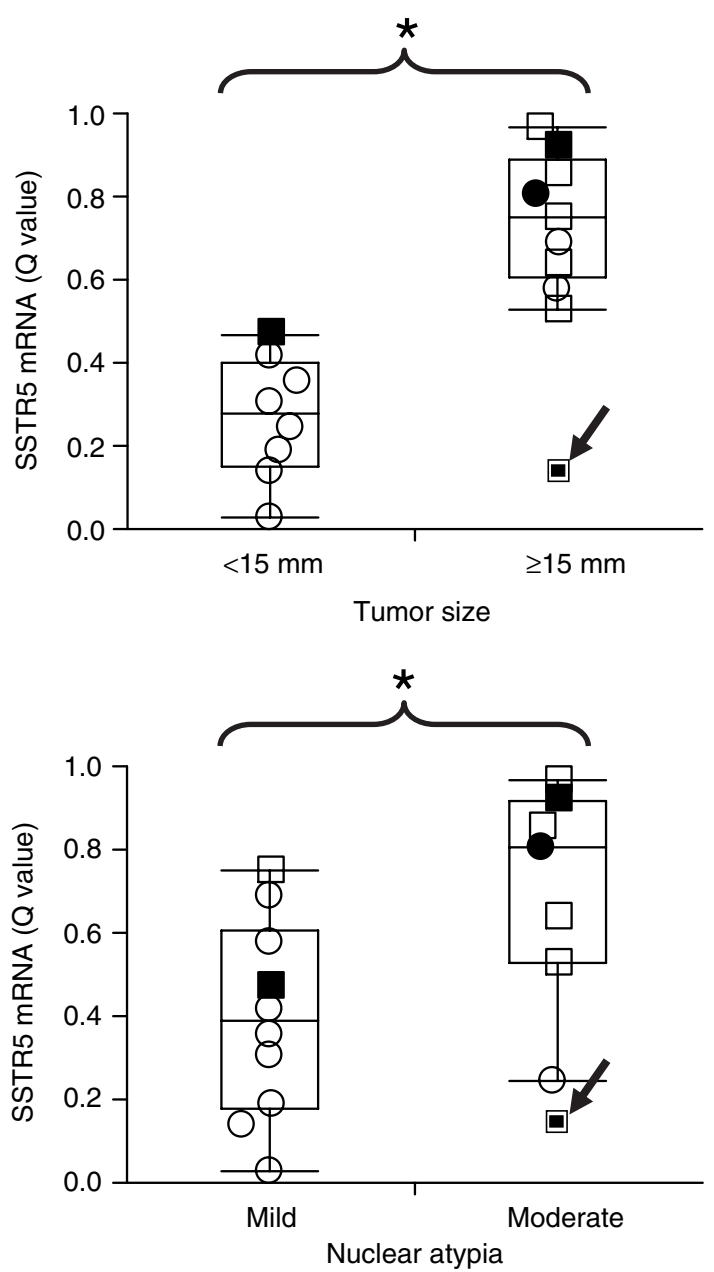

Figure 4 SSTR5 quantitative mRNA expression in insulinoma samples from patients classified accordingly to tumour size (upper panel) and nuclear atypia (lower panel). Arrows on both panels are indicating patient \#14 as mentioned in the text. Please, see legend of figure 3 for more detailed explanations. ( $\bigcirc$, WDET-BB; $\square$, WDET-UB; $\bigcirc$, WDEC; $\mathbf{\square}$, MEC; and $\square$ tumour with grow in soft agar medium, patient \#14).

approach. Octreotide and lanreotide bind preferentially to SSTR subtype 2 and, in our experience, as much as in several reports in the literature (Dogliotti et al. 2001), limited clinical responses concerning control of both insulin secretion and tumoural growth have been observed following their use in the treatment of insulinomas. SOM-230 is a novel SST analog that, compared with octreotide, demonstrates a 30 - to 40 fold higher affinity for SSTR subtypes 1 and 5 (Bruns et al. 2002). In the present study, these two SSTR subtypes were present in $100 \%$ of the tumours. Given that SSTR1 and SSTR5 may have an inhibitory effect on cell proliferation and that SSTR5 is involved in

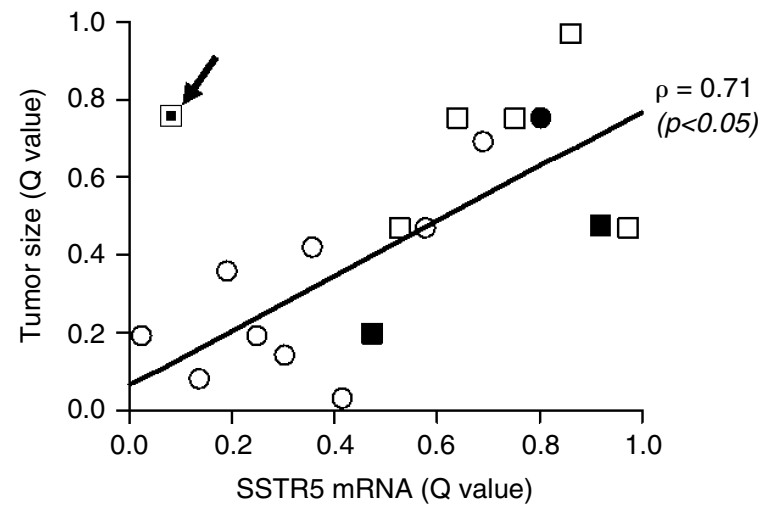

Figure 5 Correlation analysis between SSTR5 quantitative mRNA expression and insulinoma size showing a statistically significant positive Spearman's coefficient $(\rho)$ of correlation. Please, see legend of figure 3 for more detailed explanations. ( , WDET-BB; $\square$, WDET-UB; $\bigcirc$, WDEC; $\mathbf{\square}$, MEC; and $\square$ tumour with grow in soft agar medium, patient \#14).

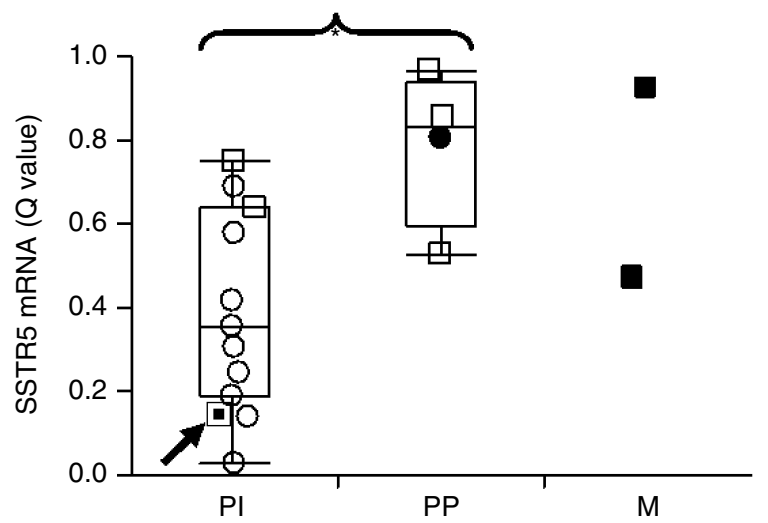

Figure 6 SSTR5 quantitative mRNA expression in insulinoma samples from patients classified accordingly to their hormonal functionality: primary tumours (PT), plurihormonal primary tumours (PP) and metastases (M). Please, see legend of figure 3 for more detailed explanations. ( $\bigcirc$, WDET-BB; $\square$, WDET-UB;, WDEC; $\square$, MEC; and $\square$ tumour with grow in soft agar medium, patient \#14).

insulin secretion control (Lamberts et al. 2002), SOM230 would have the potential to promote size reduction and inhibition of insulin secretion in insulinomas.

SSTR 5 mRNA expression was significantly higher in primary plurihormonal tumours which expressed SST and glucagon in comparison to primary insulinomas that did not express these hormones. Previous in vitro studies suggest that SST upregulates its receptors. An exposure of SST for 48 hours significantly increases receptor binding and SSTR subtypes 1-5 mRNA levels in a pituitary cell line (Bruno et al. 1994). Agonist 
treatment of stable CHO-Kl cells individually expressing the five human SSTR subtypes elicit up-regulation of SSTR subtype 2 and 5, after $60 \mathrm{~min}$ exposure (Hukovic et al. 1996). Although prolonged exposure to SST has not been evaluated, these results suggest a modulation of SSTR expression by SST, but further in vitro studies are necessary to address this issue in pancreatic $\beta$ cells. Moreover, it would be reasonable to accept that expression of more than one hormone in insulinoma, especially glucagon, would be related to a more aggressive behaviour since glucagonomas are rare gastrointestinal tumours considered to be malignant in the 200 cases reported so far (Soga \& Yakowa 1998). It is possible that plurihormonal insulinomas present a more aggressive behaviour in comparison to pure insulinomas.

In conclusion, this is the first study that demonstrates an association between the expression of a SSTR subtype and variables related to the biological behaviour in insulinomas. The positive correlation between SSTR 5 expression and tumour size suggests that the use of SST analogues more specific to SSTR5 in the treatment of insulinomas deserves attention.

\section{Funding}

This investigation was supported by Research Grants from FAPESP (No. 00/08448-0 and 00/14674-3).

\section{Acknowledgements}

We would like to thank Ana Tereza Santomauro and Fadlo Fraige Filho for referring patient \#16, to the clinical staffs of Diabetes Unit and Surgery Division of Hospital das Clínicas (University of São Paulo School of Medicine), and to Ricardo R. Giorgi for support and technical assistance. We are greatful to Karin Krogh and Mari Cleide Sogayar for expertise in soft agar assays. Gratitude is also extended to Norisa A Herrera for her constant assistance throughout this investigation. There is no conflict of interest that would prejudice the impartiality of this article.

\section{References}

Bertherat J, Tenenbaum F, Perlemoine K, Videau C, Alberini JL, Richard B, Dousset B, Bertagna X \& Epelbaum J 2003 Somatostatin receptors 2 and 5 are the major somatostatin receptors in insulinomas: an in vivo and in vitro study. Journal of Clinical Endocrinology and Metabolism 88 5353-5360.

Bruno JF, Xu Y \& Berelowitz M 1994 Somatostatin regulates somatostatin receptor subtype mRNA expression in GH3 cells. Biochemical and Biophysical Research Communications 202 1738-1743.

Bruns C, Lewis I, Briner U, Meno-Tetang G \& Weckbecker G 2002 SOM230: a novel somatostatin peptidomimetic with broad somatotropin release inhibiting factor (SRIF) receptor binding and a unique antisecretory profile. European Journal of Endocrinology 146 707-716.

Buscail L, Saint-Laurent N, Chastre E, Vaillant JC, Gespach C, Capella G, Kalthoff H, Lluis F, Vaysse N \& Susini C 1996 Loss of sst 2 somatostatin receptor gene expression in human pancreatic and colorectal cancer. Cancer Research 56 1823-1827.

Cordelier P, Esteve JP, Bousquet C, Delesque N, O'Carroll AM, Schally AV, Vaysse N, Susini C \& Buscail L 1997 Characterization of the antiproliferative signal mediated by the somatostatin receptor subtype sst5. PNAS 94 9343-9348.

Delesque N, Buscail L, Esteve JP, Saint-Laurent N, Muller C, Weckbecker G, Bruns C, Vaysse N \& Susini C 1997 sst2 somatostatin receptor expression reverses tumorigenicity of human pancreatic cancer cells. Cancer Research 57 956-962.

Dogliotti L, Tampellini M, Stivanello M, Gorzegno G \& Fabiani L. 2001 The clinical management of neuroendocrine tumours with long-acting repeatable (LAR) octreotide: comparison with standard subcutaneous octreotide therapy. Annals of Oncology 12 S105-S109.

Hallin M \& Jurěková J 1999 Optimal tests for autoregressive models based on autoregression rank scores. Annals of Statistics 27 1385-1414.

De Herder WW, Hofland LJ, van der Lely AJ \& Lamberts SW 2003 Somatostatin receptors in gastroentero-pancreatic neuroendocrine tumours. Endocrine-Related Cancer 10 451-458.

Hukovic N, Panel R, Kumar U \& Patel YC 1996 Agonist-dependent regulation of cloned human somatostatin receptor types 1-5 (hSSTR 1-5): subtype selective internalization or upregulation. Endocrinology 137 4046-4049.

Jais P, Terris B, Ruszniewsk P, LeRomancer M, Reyl-Desmars F, Vissuzaine C, Cadiot G, Mignon M \& Lewin MJ 1997 Somatostatin receptor subtype gene expression in human endocrine gastroentero-pancreatic tumours. European Journal of Clinical Investigation 27 639-644.

Kubota A, Yamada Y, Kagimoto S, Shimatsu A, Imamura M, Tsuda K, Imura H, Seino S \& Seino Y 1994 Identification of somatostatin receptor subtypes and an implication for the efficacy of somatostatin analogue SMS 201-995 in treatment of human endocrine tumors. Journal of Clinical Investigation 93 1321-1325.

Komminoth P, Perren A, Oberg K, Rindi G, Heitz PU \& Kloppel 2004 Insulinoma. In: DeLellis RA, Lloyd RV, Heitz PU, Eng C, eds. World Heath Organization Classification of Tumour. Pathology and Genetics of 
Tumours of Endocrine Organs, pp 183-186. Eds IARC Press, Lyon.

Kulaksiz H, Eissele R, Rossler D, Schulz S, Hollt V, Cetin Y \& Arnold R 2002 Identification of somatostatin receptor subtypes 1, 2A, 3, and 5 in neuroendocrine tumours with subtype specific antibodies. Gut 50 52-60.

Kumar U, Sasi R, Suresh S, Patel A, Thangaraju M, Metrakos P, Patel SC \& Patel YC 1999 Subtype-selective expression of the five somatostatin receptors (hSSTR1-5) in human pancreatic islet cells: a quantitative double-label immunohistochemical analysis. Diabetes 48 77-85.

Lamberts SW, van der Lely AJ \& Hofland LJ 2002 New somatostatin analogs: will they fulfil old promises? European Journal of Endocrinology 146 701-705.

Papotti M, Bongiovann M, Volante M, Allia E, Landolfi S, Helboe L, Schindler M, Cole SL \& Bussolati G 2002 Expression of somatostatin receptor types 1-5 in 81 cases of gastrointestinal and pancreatic endocrine tumors: A correlative immunohistochemical and reverse-transcriptase polymerase chain reaction analysis. Virchows Archiv-An International Journal of Pathology 440 461-475.

Patel RC, Kumar U, Lamb DC, Eid JS, Rocheville M, Grant M, Rani A, Hazlett T, Patel SC, Gratton E \& Patel YC 2002 Ligand binding to somatostatin receptors induces receptor-specific oligomer formation in live cells. PNAS 99 3294-3299.

Patel YC 1999 Somatostatin and its receptor family. Frontiers in Neuroendocrinology 20 157-198.

Pfaffl MW 2001 A new mathematical model for relative quantification in real time RT-PCR. Nucleic Acids Research. 29 2002-2007.

Raggi CC, Calabrò A, Renzi D, Briganti V, Cianchi F, Messerini L, et al. 2002 Quantitative evaluation of somatostatin receptor subtype 2 expression in sporadic colorectal tumor and in the corresponding normal mucosa. Clinical Cancer Research 8 419-427.

Rochaix P, Delesque N, Esteve JP, Saint-Laurent N, Voight JJ, Vaysse N, Susini C \& Buscail L 1999 Gene therapy for pancreatic carcinoma: local and distant antitumor effects after somatostatin receptor sst 2 gene transfer. Human Gene Therapy 10 995-1008.

Rozen S \& Skaletsky HJ 2000 Primer3 on the WWW for general users and for biologist programmers. In Bioinformatics Methods and Protocols, pp 365-386. Eds S Krawetz \& S Misener. Totowa: Humana Press.

Service FJ, McMahou MM, O’Brian PC, Ballrad DJ 1991 Functioning insulinoma-incidence recurrence and long term survival of patients: a 60 year study. Mayo Clinic Proceedings 66 711-719.

Sestini R, Orlando C, Peri A, Tricarico C, Pazzagli M, Serio M, Pagani A, Bussolati G, Granchi S \& Maggi M 1996 Quantitation of somatostatin receptor type 2 gene expression in neuroblastoma cell lines and primary tumors using competitive reverse transcription-polymerase chain reaction. Clinical Cancer Research 2 1757-1765.

Sharma K, Patel YC \& Srikant CB 1999 C-terminal region of human somatostatin receptor 5 is required for induction of Rb and G1 cell cycle arrest. Molecular Endocrinology 13 82-90.

Soga J \& Yakuwa Y 1998 Glucagonomas/ diabetico-dermatogenic syndrome (DDS): a statistical evaluation of 407 reported cases. Journal of hepatobiliary-pancreatic surgery 5 312-319.

Solcia E, Capella C, Klöppel G 1997 Tumor of the pancreas. In: AFIP Atlas of Tumor Pathology, 3 edn, pp 120-144. Eds Armed Forces Institute of Pathology. Washington DC. 